\title{
The Essence of Literary Translation in Comparative Literature
}

\author{
Wang Lun
}

(Jingdezhen Ceramic Institute, Jingdezhen City, China, 333403)

Keywords: Literary translation; Essence; Comparative literature

\begin{abstract}
Literary translation is in fact a kind creation for literature, which involves the translator's understanding of the source-language work and the creation of the target-language work. It promotes the communication and interaction of the two literatures and now has become an indispensable existing form of comparative literature.
\end{abstract}

\section{Introduction}

Literary translation is generally regarded as an integral part in comparative literature. Every boom of literary translation in history would promote the further development of comparative literature, thus, literary translation has undoubtedly played a significant role in world literature; however, readers and writers may well neglect the status of literary translation, thinking that it is only a means to make known some foreign literature. Actually, in comparative literature, literary translation can even constitute an independent section, and combine itself into the literature of the target language.

\section{The Essence of Literary Translation}

Literary translation is normally accepted as a kind of literature, but it is distinctively based on translation. As a matter of fact, it is a kind of re-created literature. The works from literary translation must experience two stages. In the first stage, the translator needs to understand the source language text correctly, deeply, and thoroughly, including its knowledge of linguistics, society, politics, history, local customs and practices. After doing this, the translator makes his decision about the keynote of the original work. In the second stage, the translator needs to creates a new literary work on the basis of the source one by employing his mastery of the target language; furthermore, he should convert, as exactly as possible, the original literary images into the target work, thus making it understood and accepted by the target-language readers.

Literary Translation and Literary Creation. As stated above, literary translation involves two aspects.(WANG,2009:16) For the first aspect, called the shallow one, the translator transfers the original work to the target-language reader, which is just the creation for language form; for the second aspect, called the deep one, the translator creates the artistic or literary contents for the target-language reader. For literary translation the most important part is the literary equivalence of the source and target languages. Therefore, literary translation is also a kind of literary creation.

In literary creation, the writer works out a special artistic image with his profound understanding of life and literature, and then expresses the image with appropriate words and sentences. The reader, using his imagination and language, makes out and understands the artistic world that the original writer tries to show. Although literary translation is a kind of literary creation, it is different from the normal way of literary creation. The translator must play two roles in the process. Firstly, the translator is the reader of the original work. He must act as a source-language reader to understand the literary content of the original work, completely and precisely. Secondly, the translator is the writer of the target-language text. He must convert what he has formerly read and understood to almost the same literary content with the target language. Hence, in literary translation the translator acts both as the reader and the writer.

The Characteristics of Literary Translation. In literary translation, the translator may, intentionally or unintentionally, combine his own individual personalities into the newly created piece of art, including the translator's life experience, cultural background, aesthetic taste, and 
outlook on life, world and values.(WANG,2009:39) On the one hand, when choosing the source language works, the translator would select the works of writers whose life experiences and personalities are similar to his. Of course, because every individual is unique, his can't be the same as theirs. On the other hand, when understanding the source language works, the translator may interpret the works' literary images with his own aesthetic taste. Because literary translation is actually literary creation, the translator then might fuse his personal elements into the target-language text.

\section{The Role Literary Translation Plays in Comparative Literature}

Despite the long history of literary translation, it is not until 1970s that literary translation made its breakthrough in development. The remarkable contribution goes to the book After Babel-Aspects of Language and Translation written by the British Writer George Steiner. In this book, Steiner writes that we are doing the work of translation no matter what we have read or heard. Readers, actors, editors are all the translators of the written or spoken words; therefore Steiner put forward the notion that "understanding is also translation". Although the theories about literary translation are not sound, its significance in comparative literature can never be overlooked.

The Translator's Key Role in Comparative Literature. In the development of comparative literature, translation has played the most important part. Without translation, mutual literary understanding and communication cannot be realized; without the translator's hard work, comparative literature cannot be conducted. In literary translation, the translator also serves as the writer of literature. His work of art has a profound influence over the target-language literature.

Take Lin Shu's literary translation as an example, his translated masterpieces such as The Lady of the Camellias, Uncle Tom's Cabin broadened the horizon of the Chinese literati at that time, and promoted the rise and development of contemporary Chinese novels. Another example is Zhu Shenghao, who devoted himself to translating Shakespeare's works. From the year 1935, Zhu began to translate Shakespeare's works, and in the following ten years, he translated 27 volumes of his works. His literary translation introduced to Chinese readers the great British playwright-Shakespeare, and enriched Chinese literature. Even now, Zhu's literary translation takes its place in comparative literature.

Literary Translation's Role in Literature Communication and Interaction. Literary translation makes it possible for the communication and interaction of world literature. In a book published in 1970s on contemporary French history, literary translation from German, English, Italian, Russian, and Latin is regarded as an integral part of French literature. This book makes a detail description of the publication, research, and acceptance of the translated works, not unlike the description of a French work. It shows that literary translation's significance in comparative literature is highly regarded. This phenomenon does not happen only in France; in Russia, Germany, and Britain, literary translation is also thought high of. For example, in Britain two books on literary history, Cambridge Concise British Literary History and Outline of Literary History, have been published recently. In the former book, 182 translators and 234 translated works are mentioned; in the latter, 65 translators and 105 translated works. By these two books, the role of literary translation in comparative literature can be exhibited.

The famous American poet Ezra Pound once said, "Literature can regain its life in translation; every new trend and revival in literature began and will begin from translation. The grand era of poetry is in fact the grand era of translation."

\section{The Nature of Literary Translation in Comparative Literature}

For a rather long time, people have developed a bias towards literary translation, which is that translation is just to change the source language to the target language; therefore, translation is seen as a very easy job. If a person knows a little foreign language and is capable of using a foreign-language dictionary, he is surely to do literary translation.(XIE,2011:130) This bias, to a large extent, influences people's view on literary translation and on the translator. The job and 
product of the translator are both looked down upon by the public. Literary translation is not only related to translation, but also to literature. The translated works are not only related to the change of languages, but also to the creative labor of the translators.

Literary Translation is not Foreign Literature. According to translated literature, some people would like to call it foreign literature, because they think the original writer is foreign. Although it is translated into the native language, its original thought belongs to the foreign writer. Objectively speaking, these people have neglected the creative job the translator has done in the process of the translation.

Let's take Fu Lei's translated work Father Goriot as an example. If you ask who the author of the novel Father Goriot is, you will probably be told Balzac; however, Balzac can only be called the author of the French version of Father Goriot, the real author of the Chinese version is Fu Lei. Because Balzac could not write in Chinese, of course Fu Lei is the writer of the Chinese version for Father Goriot. So the Chinese version of Father Goriot is a part of Chinese literature, not foreign literature.

The Translated Work is an Existing form of Comparative Literature. If viewed from linguistic aspect, translation is the change of the languages; if viewed, however, from literary aspect, literary translation is an existing form of comparative literature. As is known to all, a work will take its original literary form when the author completes it. But it may have other forms of existence, for example, form of opera, form of film, form of TV series, form of music, or form of translation. With the boom of translation, many outstanding works have had and will have their translated forms; some may even have more than one translated version within one foreign language. For instance, the Chinese famous novel Honglou Meng has two English versions: A Dream of Red Mansions and The Story of the Stone. The translated version can spread the literature of the source culture, and promote the communication and interaction of the two languages and literatures. Thus, the translated work is a kind of existing form in comparative literature.

\section{Conclusion}

Literary translation involves the translator's understanding of the source-language work and creation of the target-language work; so the translator and the translated work play a very significant role in comparative literature. Literary translation is of great importance to the communication and interaction of the two literatures, and it should be regarded as an indispensable existing form of comparative literature.

\section{Acknowledgement}

This essay is funded by Humanities and Social Sciences Project of Jiangxi Province (2016), NO: YY161001

\section{References}

[1]Bassnett, Susan\&Lefevere, Andre. Constructing Cultures: Essays on Literary Translation[M].Shanghai Foreign Language Education Press, 2001.

[2] Bassnett, Sussan. Comparative Literature--A Critical Introduction[M].Wiley-Blackwell,1993.

[3] WANG Ping. Aesthetics of Literary Translation[M]. Beijing: National Defense Industry Press, 2009.

[4] XIE Tian-zhen. Comparative Literature and Translation Studies[M]. Fudan University Press, 2011.

[5]YUE Dai-yun. A Concise Course of Comparative Literature[M]. Beijing: Beijing University Press, 2003.

[6]YE Xu-min. Theory and Practice of Comparative Literature[M]. Wuhan: Wuhan University Press, 2004. 


\section{Author in brief}

Wang Lun, born in 1977, is associate professor of Jingdezhen Ceramic Institute, researching in literary translation and comparative literature. 